\title{
Discourse Analysis of Trilateral Partnership
}

\author{
-Gaurav Bhattarai ${ }^{1}$
}

\begin{abstract}
This article analyzes the proposed idea of trilateral partnership between India, China and Nepal as a discourse. Available documents on proposed trilateral partnership, speeches and statements delivered by government key leaders, newspaper reports, public opinions and views related to the idea of trilateralism have been analyzed for this discourse. This article sheds light on the India's response to the trilateral partnership floated by Nepal and China's response to the same.
\end{abstract}

Keywords:

Trilateralism, discourse, China, India, Nepal

\subsection{Trilateralism as a Discourse:}

Since Nepal has been endowed with assorted metaphors to interpret its geopolitical location, these metaphors seeks differentiations and distinctions. The concept of Nepal as a link between India and China, and the age-old analogy of Nepal as a yam between two rocks often find mention. To replace the idea of the poor old yam being squashed between two rocks, some propose more modern analogies such as a cog between two wheels (Subedi, 2016, p.53). Although the idea of bridge is replacement to the old metaphor of "Buffer" and "Yam," it has been limited to an idea or discourse just like the idea of "Nepal as a transit state" is, or as trilateralism. Some also see all of these new metaphors as the extension of Nepal's equi-distance foreign policy, which is at least inscribed in policy papers.

Although the idea of 'bridge', 'trilateralism' and 'transit' are hitherto confined to discourse, they are different concepts which give the same message that Nepal's geopolitical situation has both opportunities and threats. Trilateralism priorities on the partnerships between China, India and Nepal on different issues ranging from trade, economy to security. It is a partnership borne out of reciprocity and interdependence between the three countries. However, bridge is simply a metaphorical representation of such a partnership particularly in terms of trade and economy. But, transit refers to a state or condition reached owing to geographical proximity, connectivity, transportation, and most importantly as a result

$1 \mathrm{He}$ is an International Relations (IR) scholar and his areas of interest are Geopolitics, Foreign Policy of Great and Emerging powers, Small State Security, Security Discourses, Democracy and Democratization. His book, "Nepal and China: All-weather Friends" has been published by Nepal Tianli. He is also a faculty at Master's in International Relations and Diplomacy (MIRD) program under Tribhuvan University. He can be reached at : gauravpraysforall@gmail.com 
of infrastructural development to eventually propel trade and business between India and China via Nepal. Such a differentiation is a need of the hour, particularly, to convince our immediate neighbors that Nepal doesn't view trilateral cooperation as a strategic concept, but as a purely economic and socio-cultural phenomenon.

Questions are also being raised whether the trilateral partnership damages Nepal's special relationship with India or it embraces the relationship in a new way. India has been recruiting Nepali youths, known as Gurkhas, into her army. Similarly, Kathmandu has also allowed the Indian embassy to distribute aid, build hospitals, schools, libraries and so on for local people. The special favor, which no other embassy enjoys, has been granted keeping in view the unique relationship between two countries.

The idea of trilateralism between China, India, and Nepal has been confined to Nepal's proposal of yielding trilateral partnership. Although statements, speeches, opinions and responses have been delivered time and again on the issue, no declarations, agreements and policies have been made to institutionalize the idea of trilateral partnership.

In recent decades, governments of Nepal have at various times articulated the idea of linking India and China. In the 1970s and 1980s, King Birendra put forward the idea of developing Nepal as a gateway between South and Central Asia. His successor King Gyanendra stated Nepal's willingness to function as a transit state, most notably at the Afro-Asia summit in 2005. Prime Minister Baburam Bhattarai proposed developing Nepal as a vibrant bridge while Prime Minister and Maoist Centre Chairman Pushpa Kamal Dahal made efforts to push forward the idea of a trilateral arrangement. Dahal discussed the concept of trilateral cooperation with the new Chinese leadership when he met President Xi Jinping in April 2013 although this was not the first time he had raised the subject. His plan to discuss trilateral cooperation with Indian Prime Minister Man Mohan Singh when he visited Delhi the same month was pre-empted by Indian External Affairs Minister Salman Khurshid, who commented that the proposal of trilateral partnership " may be too early" and out of context, since India and China were already working closely on various forums (Subedi, 2016, p.52). In Nepal, the prospect of exchange between the three countries has also been proposed at various times as Trans-Himalayan Security and Economic Cooperation (THSEC) (Adhikari, 2013).

\subsection{India's Response to Trilateral Discourse:}

India is undecided and somewhat resistant to the idea of trilateral engagement despite the fact that it is unable to isolate Nepal from China. India's current hesitation echoes its reaction to King Birendra's "Zone of Peace" proposal in 1975. It was opposed by India, primarily due to its interpretation of the proposal as an attempt by Nepal to wriggle out of India's grasp. An alternative for India is to build trilateral relations into alreadyexisting initiatives such as the sub-regional cooperation among Bangladesh, Bhutan, India and Nepal, which was one popularized as South Asian Growth Quadrangle(SAGQ). Another option is to build trilateral relations into the proposed Bangladesh, China, India, 
and Myanmar (BCIM) Economic Corridor. From Indian perspective, bringing Tibet and/or Yunnan into the SAGQ or adding Nepal to the BCIM are more practical solutions that will obviate the India-Nepal-China trilateral cooperation agenda, and keep northeast India at the center of regional initiatives. However, for Nepal, there is no benefit in linking to China via Northeast India and Myanmar. It wants the low lying Himalayan passes to provide access to China from South Asia (Subedi, 2016, p.54).

To apprehend clearly the India's response to trilateralism, it is important to bring into fore the report that was made public by Institute for Defense Studies and Analysis (IDSA) on May 15, 2013. The report was entitled as "Is India-Nepal-China trilateral Cooperation possible?" The report was the product of the round table conference participated by K.V.Rajan, Former Ambassador to Nepal, Maj Gen. Ashok Mehta, Security Analyst, Dr Abanti Bhattacharya, Associate Professor, East Asian Studies, Delhi University, Dr NiharNayak, Associate Fellow, IDSA. As mentioned in IDSA's website, the Round Table was organized to examine and analyze:

- What does this trilateral arrangement entail?

- Is there consensus in Nepal on India-China-Nepal trilateral?

- What is the purpose behind such a proposal?

- Does it impact India's security?

- Can India, Nepal and China cooperate in developmental projects?

- What would be the larger geo-political implications of such an engagement? Will this bring strain in India's Nepal policy?

According to IDSA, following are the major points that emerged during the discussion:

- Trilateralism is not a new concept since the quadrilateral relationship between IndiaChina-Nepal-Tibet existed in the pre-independence period as well.

- Trilaterialism seems to be more Lumbini-centric and India has not been very positive on Chinese involvement in Lumbini.

- Chinese response to this proposal is neither negative nor positive but there is a strong domestic support to this proposal in Nepal. But, India's response to this proposal is lukewarm.

- Unlike the economic rationality behind the proposed trilateral cooperation, given the porous border between India and Nepal and the close proximity between the two countries, presence of large number of Chinese workers or security personnel to safeguard the Chinese commercial projects in Nepal would have security concerns for India.

- Trilateral cooperation will enable China to expand its influence in South Asia, weakening India's pre-eminent position in the subcontinent. Hence, trilateral cooperation would come at the cost of India's security, economy and diplomacy. India has already fought a war with China and the Chinese intrusions have not sent a positive signal. In this 
regard, a trilateral co-operation involving China is not possible until and unless there is trust among all the three parties.

- On the other hand, the other view argued that instead of focusing too much on the security implications, it is important to acknowledge the economic rationality behind the proposed trilateral concept. Given the strong support in Nepal to the proposed trilateral cooperation, India can consider certain joint ventures especially in the hydropower sector. India cannot stop Chinese engagement in Nepal. Hence, it is better for India to participate in the trilateral arrangement and be a part of the projects, instead of allowing Chinese to be their own. Private sectors, which do not have security implications, should be encouraged to take part.

- India should reconsider its economic engagement with Nepal given the fact that Chinese are already there in Nepal. Yet, China is not contributing much to the Nepalese economy as most of the projects which are financed by them are based on loans than grants. Moreover, Chinese get their own labourers to work on these projects and they do not employ local workers. India can consider all these aspects and provide Nepal those economic benefits which are not provided by China. It was pointed out that there are examples of success stories of India-China joint cooperation in a third country particularly in the energy sector. Although, in case of Nepal it seems difficult, the previous success stories of India-china cooperation in third country situations should be considered.

- Discussion on the proposed trilateral cooperation should be encouraged at the track II level, if not at the level of track I.

- This is an idea ahead of its time. It will take some time to take off. Therefore, India should not be too alarmed or too enthusiastic about it. Unless Nepal gets its acts together and both India and Nepal reach certain level of maturity, there is not much to achieve from the trilateral cooperation.

- India needs to revisit its diplomacy. India and China should freely talk to each other about avoiding actions in each other's neighborhood. Discussion on trilateral arrangement can provide such platform to both the countries to have frank discussions. India has a problem with Chinese involvement as it has long standing border dispute with china.

- Nepal should realize its limitations. It should not unnecessarily try to play a bigger diplomatic role and hurry into this trilateral cooperation without understanding its implications. Rather, it should concentrate in protecting its own interests.

- Nepal has special relations with India, by engaging China it should not put at stake the unilateral advantage it is currently receiving from India. Both India and China can benefit from prosperous Nepal, but it will take some time. Nepal should also encourage interdependency. If India is dependent on Nepal for energy or other resources it will automatically provide Nepal with leverages over India. This can be converted into mutually beneficial relations. 


\subsection{China's Response to Trilateral Discourse:}

While Nepal is keen to achieve full-blown trilateral relations with India and China, the Government of India seems hesitant and not particularly interested. The Chinese Government, on the other hand, has already endorsed the idea of trilateral partnership in general, and of trilateral cooperation in a number of specified areas. As said by Chen Fengxiang, Vice Minister at the International Department of the CPC Central Committee that looks after South Asia, "China has expressed its willingness to promote trilateral cooperation in economy, including on hydropower development"( Rai, August 24, 2014). China's influence and interests in South Asia are driven by the state of the Chinese economy and the development in its western regions-Xinjiang, Tibet and Yunnan (Small, 2014, p.1). Meanwhile, Beijing has also forwarded the idea of China and India developing a Trans-Himalayan zone of cooperation (Mohan, July 28, 2014).

At a time when Maoist Chief Pushpa Kamal Dahal first proposed the idea of trilateral cooperation with the Chinese leadership back in 2010, he got positive response from Beijing. Now India's opposition to trilateral cooperation is established. But what about China? Wasn't President Xi Jinping serious when he said Nepal could be an 'economic bridge' between India and China during Prime Minister KP Sharma Oli's China visit back in March? When columnist Biswas Baral put this question to a close aide of former Prime Minster K P Oli, who was also involved in planning his China trip, he admitted that the trilateral idea had seemed a little 'forced' to the Chinese at the time. According to Baral, Chinese leadership in 2010 actually found it hard to give a clear 'No' to a close friend. Indeed, anyone who is even a little versed in Chinese diplomacy knows that seldom do they say 'No' outright. It's not in their genes ( Baral, Novermber 24, 2016). On October 16 of 2016, Prime Minister Pushpa Kamal Dahal during his visit to Goa, India in course of attending the BRICS- BIMSTEC Outreach Summit reintroduced the proposal for a trilateral meeting which as Dahal claims has received a positive response from Indian Prime Minister Narendra Modi and Chinese President Xi Jinping. Reminding that Gautam Buddha, Pashupatinath and Janaki connect Nepal, India and China, PM Dahal said Nepal in modern history could serve as a bridge to maintain cordial relations with India and China. On the occasion, Chinese President Xi said Nepal could serve as a bridge between India and China, saying geography of any country would not play a decisive role in terms of many things like development. He also praised the role of Nepal in keeping the relations between China and India at equidistance while expressing belief that the relations between the three neighbours would be strengthened in the future (The Kathmandu Post, Oct 16, 2016).

According to Professor Hu Shisheng( 2015, p.7) Director of the Institute of South and Southeast Asian and Oceanian Studies at China Institutes of Contemporary International Relations, "China sees Nepal as the most viable bridge between China and South Asia as the two countries share a stable border". While giving interview to The Kathmandu Post on Oct 12, 2015, Hu stated: 
Nepal is a bridge for China to enter South Asia. Even Pakistan cannot serve this purpose because of its history with India. But with Nepal, there are no such issues. We have divided South Asia in two parts, West South Asia: Afghanistan, Pakistan and East South Asia which has India at the centre. So we would like to view Nepal as a bridge to enter East South.

On Trilateralism, Hu stated during the interview that:

China is open to this agenda. Even when the Indian leader [Indian Prime Minister Narendra Modi] had visited China recently, Chinese leaders had openly spoken about this. Both the countries can achieve far more if they cooperate. India and China should coordinate with one another in South Asia just as they worked together and achieved success in Myanmar and Iran. China is willing to work with India even in Sri Lanka although India might be a bit suspicious. The Nepal earthquake has also given us an opportunity to work together. And this way, we can facilitate and promote connectivity across the Himalayas.

$\mathrm{Hu}$ also made it clear that China does not want to compete with India in South Asia because the smaller countries bordering India will be put in an awkward position by having to choose a side. It does not want small countries in the region to suffer because of SinoIndian relations.

Similarly, Spokesperson of Chinese Foreign Ministry Hua Chunying has also expressed Beijing's interest in exploring trilateral cooperation. She underscored China's conviction that trilateral partnership would be good for regional stability and development and spoke of Beijing's interest in exploring such a partnership (Parajuli, Oct 19, 2016). Her opinion came in the wake of Indian foreign ministry spokesperson Vikas Swarup's assertion that the Goa meeting of Nepali Prime Minister Pushpa Kamal Dahal, Chinese President Xi Jinping and India Prime Minister Narendra Modi on the sidelines of the BRICS summit was not a trilateral event. Swarup had said:

"It was just entirely coincidental that... in the leaders' lounge, all three were present at the same time. The bilateral between Nepal and China had already ended, so I don't know on what basis people are calling it a trilateral and all that. It is perfectly normal in a multilateral setting for leaders to be together in a lounge on the sidelines somewhere else. So I don't think you need to read too much into that."

However, Nepali Prime Minister Pushpa Kamal Dahal claimed that he put forward the idea of trilateral strategic cooperation and partnership among three countries and both leaders described the proposal as positive. Dahal said so while talking to reporters back home upon his arrival at Tribhuvan International Airport (TIA). 


\section{Conclusion:}

Trilateralism is still an idea in the making; it has not been developed into institutions. However, Nepal has shown imagination in leapfrogging from bilateral to trilateral arrangements, and in engaging stakeholders in India and China. Materialization of trilateralism not only requires a new order of diplomatic collaborations between India and China but Nepal also need to find a way to convince its neighbors that it does not favor one at the cost of the other. They need to be convinced that trilateralism is mutually advantageous to both India and China for long term strategic connectivity. Trilateral partnership is the best way for China to actively seek access to South Asia, or in other words there is a big market for China in South Asia. Similarly, it will benefit India by giving India access to Tibet, and possibly even to Xinjiang and further on to Central Asia. But, prior that the political and security issues among India, China and Nepal should be addressed. The three countries will have to work domestically to put this vision in a perspective. Nepal has to settle its internal problems in a more meaningful manner and forge national consensus on how to relate itself with India and China.

To make trilateralism a reality, trust deficits prevalent between them should be erased. When Nepal and China come closer, India's discomfort has been visible. When China and India get closer, probably Nepal feels discomfort of losing its strategic space. India on its part must dare to address the Chinese sensitivities. In fact, the Asian century cannot be conceived on the premise of Sino-Indian conflict and rivalry.

\section{Works Cited:}

Adhikari, Rishi.,Chulagain Y P., Dhakal, T P \&ShyamBandhuSubedi. (2013). From a Buffer towards a Bridge: Nepal's New Foreign Policy Agenda. Kathmandu: Institute of Foreign Affairs(IFA),

Baral, Biswas.(2016, November 24). Trilateralism, RIP. Op-ed.Republica,

Mohan, C.Raja. (2014, July 28). Modi Government's Challenges in Nepal. Op-ed. Eurasia Review,

Rai, Dewan. (2014, August 24). Neighbors High on China's Foreign Policy Agenda. The Kathmandu Post. Retrieved from http://kathmandupost.ekantipur.com/printedition/news/2014-08-24/ neighbours-high-on-chinas-foreign-policy-agenda.html,

Small, Andrew. (2014). Regional Dynamics and Strategic Concerns in South Asia: China's Role. Centre for Strategic and International Studies,

Subedi, Jiwan. (2016). Nepal's Evolving Bilateral Relations with India and China, and the Question of Trilateralism. In Pramod Jaiswal \&GeetaKochhar (Eds.), India-China-Nepal, Decoding Trilateralism(pp. 27-60). New Delhi: G.B.Books,

The Kathmandu Post. (2016, October 16). India, China Welcome Nepal's Proposal on Tri-party Understanding. Retrieved from http://kathmandupost.ekantipur.com/news/2016-10-16/indiachina-welcome-nepals-proposal-on-tri-party-understanding.html, 
42 KMC Journal 